\title{
The Role and Impact of Operating Theatre Background Music on Users and Patients: Opinion of Theatre Staff
}

\author{
Rex Friday Ogoronte A. Ijah, Solomon. N. Elenwo, Joy O. Dayi, \\ Friday E. Aaron, Rose E. Oko-Jaja, Vitalis O. Ofuru
}

ABSTRACT

Aim: To determine the opinion of operating theatre users on the role of operating theatre background music on theatre users and patients in tertiary health care facilities in Port Harcourt.

Background: The relationship between music and health has been described by researchers. Music has been used in several hospital settings with effects which some consider beneficial and others harmful.

\begin{abstract}
Materials and Methods: This cross-sectional descriptive study was carried out among theatre users from March to June 2020 in two multispecialty tertiary healthcare facilities in Port Harcourt Nigeria. Using the convenience sampling method, data collected with pretested semistructured questionnaires were analyzed using the Statistical Package for the Social Sciences (SPSS) version 20.0.
\end{abstract}

Results: One hundred and twenty-one $(82.9 \%)$ respondents asserted to knowledge of relationship between music and stress hormone. 97 (66.4\%) agreed that music has positive effect on workers in the operating theatre. One hundred and seventeen $(80.1 \%)$ respondents were of the opinion that background music in the operating theatre is not a distraction, while 22 (15.1\%) respondents felt otherwise. One hundred and forty-four $(\mathbf{9 8 . 8 \%})$ respondents agreed to usefulness of background music while at work. High proportion of respondents who lack knowledge of the relationship between stress hormone and music had no preference for operating theatre background music and the relationship was statistically significant $(\mathbf{P}<\mathbf{0 . 0 5})$.

Conclusion: Operating theatre background music is useful as opined by the majority of operating theatre staff, though its preference is low among those with less knowledge of the positive relationship between such music and stress hormones.

Keywords: Background music, healthcare facilities, Nigeria, operating theatre, tertiary Port Harcourt.

Published Online: September 13,2021

ISSN: $2736-5476$

DOI: 10.24018 /ejclinicmed.2021.2.5.19

R. F. O. A. Ijah*

Department of Surgery, University of Port Harcourt Teaching Hospital, Port Harcourt, Nigeria.

(e-mail: rexijah@gmail.com)

S. N. Elenwo

Department of Surgery, University of Port Harcourt Teaching Hospital, Port Harcourt, Nigeria.

J. O. Dayi

Department of Anaesthesia, University of Port Harcourt Teaching Hospital, Port Harcourt, Nigeria.

F. E. Aaron

Department of Surgery, Rivers State University Teaching Hospital, Port Harcourt, and Senior Lecturer, Rivers State University, Port Harcourt, Nigeria. R. E. Oko-Jaja

Department of Nursing, University of Port Harcourt Teaching Hospital, Port Harcourt, Nigeria.

V. O. Ofuru

Department of Surgery, University of Port Harcourt Teaching Hospital, Port Harcourt, Nigeria.

*Corresponding Author

\section{INTRODUCTION}

Music is a valuable art used in different parts of the world in virtually all disciplines. Different types of music have been described [1], [2] with individual having their preferences [3]-[6]. Some features are, however, common to all music: a combination of sounds that are pleasant to the ear; [7]-[9] carries a massage; [10]-[13] and an expression evoking some emotion [14]-[19]. Music is considered background when it is not intended to distract attention from the focus of activity [20], [21] A study demonstrated significant improvement in task performance among a set of primary school pupils exposed to calm relaxing background music compared to the control [22]. In this same study, music that was unpleasant, arousing, and aggressive negatively affected performance
[22]. Also, in restaurant business, background music has been reported to have positively affected purchases and length of stay of customers [23].

The relationship between music and health has been described by researchers [24]-[28]. In a narrative review, a researcher reported that compared to silence, use of soothing music could reduce stress and blood pressure among patients and caregiving nurses [29]. Music has been used in hospital setting among children, [30]-[33] in supportive cancer care,[34],[35] in psychiatric patients,[36] among the mentally retarded, [37] for the elderly for psychologic wellbeing, [38] in hospital waiting rooms, [39] for relieving anxiety in preoperative setting, [40] in intensive coronary care unit, [41] in anxiety care among the terminally ill [42], [43] and for anxiety and pain care [44]-[46]. A proposal has been made for music usage in many hospital settings [47]. 
The opinion of theatre users in our environment on the use of music in theatre has not been ascertained and needs to be studied since music appreciation differs in different settings and among different persons. The knowledge of background theatre music, the benefits (or otherwise) of background theatre music, and the opinions and preferences of theatre users in our environment on the subject were investigated and presented in this study.

\section{MATERIALS AND METHOD}

\section{A. Study Area}

The study was carried in Port Harcourt the capital of Rivers State, one of the Niger Delta States in the Federal Republic of Nigeria.

\section{B. Study Place and Period}

The operating theatres and the specialist surgical outpatient clinics of University of Port Harcourt Teaching Hospital (UPTH) and the Rivers State University Teaching Hospital (RSUTH) in Port Harcourt were the places the study was carried out, between March 2020 and June 2020.

\section{Study Design}

A cross-sectional descriptive study.

\section{Study Population}

The study was carried out among theatre users comprising surgeons, anaesthetists, theatre nurses, technicians, and students.

\section{E. Sample Size Determination}

The minimum sample size of 146 (about half of the total population) was determined based on a projected total available theatre users' population of about 300 .

\section{F. Sampling Technique Procedure}

The convenience sampling method was used to recruit respondents among all the theatre users present at the tertiary health facility who gave consent for the study. A total of two hundred and fifty (250) self-administered semi-structured questionnaires intended for the study were distributed (with effort made to avoid double administration) between March 2020 and June 2020, and one hundred and forty-six (146) were retrieved.

\section{G. Data Analysis}

Information on socio-demographic characteristics; role, knowledge, uses of music; impact of operating theatre background music on theatre users; and opinion on operating theatre background music for action; were collated and analyzed using the Statistical Package for the Social Sciences (SPSS) version 20.0.

\section{RESULTS}

A total of 146 respondents were recruited for the study. The demographic characteristics as in Table I showed that majority of the respondents were persons over 25 years of age, and those who have spent more than 10years in service. The male-female ratio of respondents was almost equal, and the surgeons were more in number than any other category of theatre users.

TABLE I: SOCIO-DEMOGRAPHIC CHARACTERISTICS OF STAFF RESPONDENTS

\begin{tabular}{|c|c|c|}
\hline Variables & Frequency & Percentage \\
\hline $\operatorname{Sex}$ & 146 & 100 \\
\hline Male & 74 & 50.7 \\
\hline Female & 72 & 49.3 \\
\hline Age & 146 & 100 \\
\hline $\begin{array}{l}\text { Less than } 25 \\
\text { years }\end{array}$ & 6 & 4.1 \\
\hline $25-40$ Years & 69 & 47.3 \\
\hline $41-60$ years & 71 & 48.6 \\
\hline Marital Status & 146 & 100 \\
\hline Single & 44 & 30.1 \\
\hline Married & 101 & 69.2 \\
\hline Divorced & 1 & .7 \\
\hline Years in service & 146 & 100 \\
\hline Less than 1 Year & 20 & 13.7 \\
\hline $1-10$ years & 45 & 30.8 \\
\hline $11-20$ years & 66 & 45.2 \\
\hline $21-30$ years & 13 & 8.9 \\
\hline $\begin{array}{l}\text { More than } 30 \\
\text { years }\end{array}$ & 2 & 1.4 \\
\hline Religion & 146 & 100 \\
\hline Christianity & 141 & 96.6 \\
\hline Islam & 5 & 3.4 \\
\hline $\begin{array}{l}\text { Health } \quad \text { staff } \\
\text { category }\end{array}$ & 146 & 100 \\
\hline $\begin{array}{l}\text { Surgeons (All } \\
\text { Specialties) }\end{array}$ & 60 & 41.1 \\
\hline Anesthetist & 14 & 9.6 \\
\hline Theatre nurse & 49 & 33.6 \\
\hline $\begin{array}{l}\text { Others } \\
\text { (Technician, Etc.) }\end{array}$ & 23 & 15.8 \\
\hline Place of work & 146 & 100 \\
\hline UPTH & 105 & 71.9 \\
\hline RSUTH & 41 & 28.1 \\
\hline
\end{tabular}

Table II shows the opinion of respondents on the knowledge and role of music. One hundred and forty-one $(96.6 \%)$ respondents love listening to music at home. Additionally, $121 \quad(82.9 \%)$ asserted to knowledge of relationship between music and stress hormone. One hundred and fifteen $(78.8 \%)$ respondents asserted positively to knowledge of the relationship between music and mood, while 97 (66.4\%) agreed that music has positive effect on workers in the operating theatre.

TABLE II: Role, KNOWLEDGE AND USES OF Music OUTSIDE HosPitAL SETTING

\begin{tabular}{|c|c|c|}
\hline Variables & Frequency & Percentage \\
\hline Love listening to music at home & 146 & 100 \\
\hline Yes & 141 & 96.6 \\
\hline No & 2 & 1.4 \\
\hline Don't know & 3 & 2.1 \\
\hline knowledge & & \\
\hline $\begin{array}{l}\text { relationship between music } \\
\text { and stress hormone }\end{array}$ & 146 & 100 \\
\hline Yes & 121 & 82.9 \\
\hline No & 11 & 7.5 \\
\hline Not sure & 14 & 9.6 \\
\hline Have knowledge about positive & & \\
\hline $\begin{array}{l}\text { relationship between music } \\
\text { and mood }\end{array}$ & 146 & 100 \\
\hline Yes & 115 & 78.8 \\
\hline No & 15 & 10.3 \\
\hline Not sure & 16 & 11.0 \\
\hline $\begin{array}{l}\text { Effect of music in the operating } \\
\text { theatre }\end{array}$ & 146 & 100 \\
\hline Positively & 97 & 66.4 \\
\hline Negatively & 3 & 2.1 \\
\hline Not sure & 13 & 8.9 \\
\hline Not played in our theatre & 33 & 22.6 \\
\hline
\end{tabular}

Table III shows the impact of operating theatre background 
music on theatre users. One hundred and seventeen $(80.1 \%)$ respondents were of the opinion that background music in the operating theatre is not a distraction, while 22 (15.1\%) respondents felt it was a distraction. On expressing the negative impact of music, $37(25.3 \%)$ respondents felt that music impairs ability to detect alarm/sounds from theatre machines, $10(6.8 \%)$ asserted to possible loss of concentration, while $95(65.1 \%)$ affirmed that it has no negative impact in the operating theatre. However, 144 $(98.8 \%)$ respondents agreed to usefulness of background music while at work, $2(1.6 \%)$ felt otherwise. Out of the total respondents who positively asserted to usefulness of background music, $39(26.7 \%)$ felt that it calms the mind while at work, $16(11.0 \%)$ opined that it reduces stress of official work, and $37(25.3 \%)$ asserted to reduction in boredom of a long surgery. Fifty-two $(35.6 \%)$ respondents agreed with all three options mentioned above for usefulness of music.

TABLE III: IMPACT OF OPERATING THEATRE BACKGROUND MUSIC ON THEATRE USERS

\begin{tabular}{|c|c|c|}
\hline Variables & Frequency & Percentage \\
\hline $\begin{array}{l}\text { Music in operating theatre is a } \\
\text { distraction }\end{array}$ & 146 & 100 \\
\hline Yes & 22 & 15.1 \\
\hline No & 117 & 80.1 \\
\hline Not sure & 7 & 4.8 \\
\hline How music distract/disturbed work & 146 & 100 \\
\hline Causes loss of concentration & 10 & 6.8 \\
\hline $\begin{array}{l}\text { Impairs ability to detect } \\
\text { alarm/sounds from theatre machines }\end{array}$ & 37 & 25.3 \\
\hline $\begin{array}{l}\text { Impairs communication among } \\
\text { colleagues in theatre }\end{array}$ & 4 & 2.7 \\
\hline No distraction & 95 & 65.1 \\
\hline How music helps while at work & 146 & 100 \\
\hline Calms the mind while at work & 39 & 26.7 \\
\hline Reduces stress of official work & 16 & 11.0 \\
\hline $\begin{array}{l}\text { Reduces the boredom of a long } \\
\text { surgery }\end{array}$ & 37 & 25.3 \\
\hline All of the above & 52 & 35.6 \\
\hline None & 2 & 1.4 \\
\hline
\end{tabular}

Table IV shows the preferences and opinions of respondents on operating theatre background music for action. One hundred and four (78.1\%) respondents indicated positive preference for operating theatre background music at work, while $27(18.4 \%)$ respondents affirmed in the negative. In defining background theatre music, the assertions were: music must not hinder ability to hear and listen to one another - $28(19.2 \%)$ by respondents; music that does not hinder ability to detect monitors' alarm/sound - 29 (19.9\%) respondents; music that does not negatively affect ability to concentrate $42(28.8 \%)$; and $47(32.2 \%)$ respondents asserted to all the above options.

TABLE IV: PREFERENCES AND OPINION ON OPERATING THEATRE BACKGROUND MUSIC FOR ACTION

\begin{tabular}{lcc}
\hline \hline \multicolumn{1}{c}{ Variables } & Frequency & Percentage \\
\hline \hline $\begin{array}{l}\text { Staff preference for operating theatre } \\
\text { background music while at work }\end{array}$ & 146 & 100 \\
$\quad$ Yes & 114 & 78.1 \\
$\quad$ No & 27 & 18.5 \\
$\quad \begin{array}{l}\text { Not sure } \\
\text { Opinion on what is operating theatre }\end{array}$ & 5 & 3.4 \\
background music & & \\
$\begin{array}{l}\text { Does not hinder ability to hear and } \\
\text { listen to one another }\end{array}$ & 28 & 19.2 \\
$\begin{array}{l}\text { Does not hinder ability to detect } \\
\text { monitors' alarm/sound }\end{array}$ & 29 & 19.9 \\
$\begin{array}{l}\text { Does not negatively affect ability } \\
\text { to concentrate }\end{array}$ & 42 & 28.8 \\
$\begin{array}{l}\text { All of the above } \\
\text { Opinion on what is unfavorable } \\
\text { operating theatre music }\end{array}$ & 47 & 32.2 \\
$\begin{array}{l}\text { Music that hinders ability to hear } \\
\text { and listen to one another }\end{array}$ & 146 & 100 \\
$\begin{array}{l}\text { Music that hinders ability to detect } \\
\text { monitors' alarm/sound }\end{array}$ & 23 & 15.8 \\
$\begin{array}{l}\text { Music that negatively affect ability } \\
\text { to concentrate }\end{array}$ & 27 & 18.4 \\
All of the above & 54 & 37.0 \\
\hline \hline
\end{tabular}

The relationship between preference for operating theatre background music and knowledge about relationship between music and stress hormone was presented in Table V. It appears that knowledge of the relationship between music and stress hormones influence respondents' preference as high proportion of those who lack such knowledge had no preference for operating theatre background music and the relationship was statistically significant $(\mathrm{P}<0.05)$.

TABLE V: RELATIONShip BETWEEN PREFERENCE FOR OPERATING THEATRE BACKGROUND MuSIC AND KNOWLEDGE ABOUT RELATIONSHIP BETWEEN MUSIC AND STRESS HORMONE

\begin{tabular}{ccccccc}
\hline \hline \multicolumn{7}{c}{ Knowledge about Relationship between Music and Stress } \\
Hormone
\end{tabular}

\section{DiscusSION}

The proportion of males and females in the study is almost equal, and most respondents were in their middle age, and a sizable number had spent more than ten years in service. In a cross-cultural intercontinental study, it was found that age, country, and gender all significant influence on music listening preference [48]. We therefore reason that the almost equal distribution of the sexes of our respondents will likely remove the possible bias that differences in gender of respondents could have impacted on the results of the study.
Most respondents opined that background music in the operating theatre has no distracting effect. And for those who felt otherwise, impairment of the ability to detect alarm/sounds from theatre machines, possible loss of concentration, loss of ability to hear and listen to one another were their major concerns. These findings are in consonance with the reports from previous studies which raised issues about the use of music in operating theatre [49]-[51]. The potential effect of interference of music with personnel communication has been reported, with a call for discussions on guidance [49]-[51]. Interference of loud music with sound 
of patient breathing and monitors used in the theatre is another issue of concern especially to the anesthetist [52], [53]. Low volume (soothing) music is therefore advised [54].

Almost all respondents positively asserted to the usefulness of operating theatre background music with its potential of calming the mind while at work, reduction of the stress of official work, and reduction in boredom of long surgery. Our finding is similar to a Nigerian study which demonstrated that music usage in operating theatre has the potential of reducing annoyance, distraction, and stress among theatre staff, and decreasing anxiety among patients [55]. However, our study differs from this 2010 Nigerian study in that it was carried out among both patients and health staff with a sample size of 162 , while ours study was done only among theatre users with a sample size of 146 .

Almost all respondents asserted to love of listening to music at home, and majority demonstrated knowledge of the relationship between music and stress hormones / mood, with some positive effects. Beneficial effect of music has been reported among pre-operative day surgery patients who demonstrated anxiety-relieving effect of music [56]. A study demonstrated cortisol (stress hormone) level reduction and reduced consumption of drugs among spinal patients who listened to music [57]. Our findings however differ from this report in that ours is the expressed opinion of theatre users. A statistically significant relationship has been seen to exist between lack of knowledge of the effect of music on stress hormones and lack of preference for operating theatre background music. This finding differs and expresses a different dimension to an already documented relationship reported to exist between music listening during spinal anesthesia and cortisol level/consumption of propofol [57].

The limitation of this study is that it is questionnaire-based, expressing opinions of theatre users. There is need in future to study and establish if the assertions of respondents are real. This may be achieved by directly testing the stress hormone levels of theatre staff before and after surgery and making comparison between those who listened to operating theatre background music, after properly matching for age and gender of participants.

This study concludes that background music is beneficial in operating theatre and is desirable to a majority of theatre users. Most theatre users did not see it as distracting, rather positively asserted to the usefulness of such music with its potential of calming the mind while at work, reducing the stress of official work, and alleviating boredom of long surgery. Those who have less knowledge of the relationship between background music and stress hormones are less likely to show preference for operating theatre background music.

\section{RECOMMENDATION}

Operating theatre background music should be encouraged as majority of theatre users showed positive preference for it. This recommendation is valid within the context of the meaning and use of background music.

\section{ACKNOWLEDGMENT}

We acknowledge the department of surgery and the hospital research ethics committee for permission granted to do the study.

\section{ETHICAL CONSIDERATIONS:}

The approval of the research ethics committee of the University of Port Harcourt Teaching Hospital (UPTH) and the Rivers State University Teaching Hospital (RSUTH) were obtained before commencement of study.

\section{CONFLICT OF INTEREST}

None declared.

\section{FUNDING}

The Study was privately sponsored by the researchers.

\section{REFERENCES}

[1] E. Labbé, N. Schmidt, J. Babin and M. Pharr, " Coping with stress: the effectiveness of different types of music," Applied psychophysiology and biofeedback, 32(3): 163-168, 2007.

[2] R. McCraty, B. Barrios-Choplin, M. Atkinson and D. Tomasiono, "The effects of different types of music on mood, tension, and mental clarity," Alternative therapies in health and medicine, 4(1): 75-84, 1998.

[3] Ferwerda, B., E. Yang, M. Schedl, and M. Talcic, M. "Personality traits predict music taxonomy preferences," Proceedings of the 33rd Annual ACM Conference Extended Abstracts on Human Factors in Computing Systems. 2015.

[4] M. J. Delsing, T. F. Ter Bogt, R. C. Engels, and W. H. Meeus, "Adolescents' music preferences and personality characteristics," European Journal of Personality: Published for the European Association of Personality Psychology, 22(2): 109-130, 2008.

[5] A. LeBlanc, W. L. Sims, C. Siivola, and M. Obert, "Music style preferences of different age listeners," Journal of Research in Music Education, 44(1): 49-59, 1966.

[6] A. Bonneville-Roussy, P. J. Rentfrow, M. K. Xu, and J. A. Potter, "Music through the ages: Trends in musical engagement and preferences from adolescence through middle adulthood," Journal of personality and social psychology, 105(4): 703, 2013.

[7] M. Minsky, "Music, mind, and meaning," Springer. 1-19, 1982.

[8] R. Maconie, "The concept of music," Oxford University Press, 1993.

[9] D. Matić, "A genetic algorithm for composing music," Yugoslav Journal of Operations Research, 20(1): 157-177, 2010.

[10] C. M. Tomaino, "The role of music in the rehabilitation of persons with neurologic diseases: Gaining access to 'lost memory'and preserved function through music therapy," Music Therapy Today, 2002.

[11] S. B. Goldman, "James Baldwin's" Sonny's Blues": A Message in Music," Negro American Literature Forum. JSTOR, 1974.

[12] V. Morley, K. Somdahl-Sands, "Music with a Message," aether, 58, 2011.

[13] M. Bigliassi, "Use the brain: complementary methods to analyse the effects of motivational music," Frontiers in human neuroscience, 9 , 508, 2015.

[14] D. Cooke, "The language of music,", 1959.

[15] P. N. Juslin, J.A. Sloboda, "Music and emotion: Theory and research," Oxford University Press, 2011.

[16] J. A. Sloboda, P.N. Juslin, "Psychological perspectives on music and emotion," 2001.

[17] P. G. Hunter, E.G. Schellenberg, "Music and emotion," in Music perception, Springer. 129-164, 2010.

[18] W. F. Thompson, "Music, thought, and feeling: Understanding the psychology of music," Oxford university press, 2015.

[19] T. Eerola, J.K. Vuoskoski, "A review of music and emotion studies: Approaches, emotion models, and stimuli," Music Perception: An Interdisciplinary Journal, 30(3): 307-340, 2013. 
[20] W. Apel, "The Harvard dictionary of music," Harvard University Press, 2003.

[21] J. A. Lehmann, T. Seufert, "The influence of background music on learning in the light of different theoretical perspectives and the role of working memory capacity," Frontiers in psychology, 8: p. 1902, 2017.

[22] S. Hallam, J. Price, and G. Katsarou, "The effects of background music on primary school pupils' task performance," Educational studies, 28(2): 111-122, 2002.

[23] F. V. Garlin, K. Owen, "Setting the tone with the tune: A meta-analytic review of the effects of background music in retail settings," Journal of business research, 59(6): 755-764, 2006.

[24] R. MacDonald, G. Kreutz, and L. Mitchell, "Music, health, and wellbeing," Oxford University Press, 2013.

[25] I. N. Cabrera, M.H. Lee, "Reducing noise pollution in the hospital setting by establishing a department of sound: a survey of recent research on the effects of noise and music in health care," Preventive medicine, 30(4): 339-345, 2000.

[26] L. O. Bonde, "Health Musicing-Music Therapy or Music and Health? A model, empirical examples and personal reflections," 2011.

[27] G. Kreutz, C.Q. Murcia, and S. Bongard, "Psychoneuroendocrine research on music and health: an overview," Music, health, and wellbeing, 457-476, 2012.

[28] J. Edwards, "A music and health perspective on music's perceived "goodness"." Nordic Journal of Music Therapy, 20(1): 90-101, 2011.

[29] T. O. Iyendo, "Exploring the effect of sound and music on health in hospital settings: A narrative review," International journal of nursing studies, 63: 82-100, 2016.

[30] C. Preti, G.F. Welch, "Music in a hospital setting: a multifaceted experience," British Journal of Music Education, 21(3): 329-345, 2004.

[31] L. Avers, A. Mathur, and D. Kamat, "Music therapy in pediatrics," Clinical pediatrics, 46(7): 575-579, 2007.

[32] J. W. Stouffer, B.J. Shirk, and R.C. Polomano, "Practice guidelines for music interventions with hospitalized pediatric patients," Journal of Pediatric Nursing, 22(6): 448-456, 2007.

[33] J. Edwards, "Music therapy for children with severe burn injury," Music Therapy Perspectives, 16(1): 21-26, 1998.

[34] M. M. Stanczyk, "Music therapy in supportive cancer care," Reports of Practical Oncology \& Radiotherapy, 16(5): 170-172, 2011.

[35] E. G. Waldon, "The effects of group music therapy on mood states and cohesiveness in adult oncology patients," Journal of Music Therapy, 38(3): 212-238, 2001.

[36] J. Shuman, H. Kennedy, P. DeWitt, A. Edelblute, and M. Z. Wamboldt, "Group music therapy impacts mood states of adolescents in a psychiatric hospital setting," The Arts in Psychotherapy, 49: 50-56, 2016.

[37] K. J. Reed, "Music therapy treatment croups for mentally disordered offenders (MDO) in a state hospital setting," Music Therapy Perspectives, 20(2): 98-104, 2002.

[38] P. Laukka, "Uses of music and psychological well-being among the elderly," Journal of happiness studies, 8(2): 215, 2007.

[39] D. A. Tansik, R. Routhieaux, "Customer stress-relaxation: the impact of music in a hospital waiting room," International Journal of Service Industry Management, 1999.

[40] G. Kipnis, N. Tabak, and S. Koton, "Background music playback in the preoperative setting: does it reduce the level of preoperative anxiety among candidates for elective surgery?" Journal of PeriAnesthesia Nursing, 31(3): 209-216, 2016.

[41] H. L. Bonny, "Music Listening for lntensive Coronary Care Units: A Pilot Project," Music Therapy, 3(1): 4-16, 1983.

[42] A. Horne-Thompson, D. Grocke, "The effect of music therapy on anxiety in patients who are terminally ill," Journal of palliative medicine, 11(4): 582-590, 2008.

[43] J. Bradt, C. Dileo, "Music therapy for end-of-life care," Cochrane Database of Systematic Reviews, 1:2010.

[44] U. Nilsson, "The anxiety-and pain-reducing effects of music interventions: a systematic review,"AORN journal, 87(4): 780-807, 2008.

[45] N. Reza, S. M. Ali, K. Saeed, A. Abul-Qasim, and T. H. Reza, "The impact of music on postoperative pain and anxiety following cesarean section," Middle East J Anesthesiol, 19(3): 573-586, 2007.

[46] M. M. Tse, M. Chan, and I.F. Benzie, "The effect of music therapy on postoperative pain, heart rate, systolic blood pressure and analgesic use following nasal surgery," Journal of pain \& palliative care pharmacotherapy, 19(3): 21-29, 2005.

[47] B. J. Crowe, "Music Therapy and Physical Medicine-Expanding Opportunities for Employment," Music Therapy, 5(1): 44-51, 1985.

[48] A. LeBlanc, Y. C. Jin, L. Stamou, and J. McCrary, "Effect of age, country, and gender on music listening preferences," Bulletin of the council for Research in Music Education, 72-76, 1999.
[49] S. M. Weldon, T. Korkiakangas, J. Bezemer, and R. Kneebone, "Music and communication in the operating theatre," Journal of advanced nursing, 71(12): 2763-2774, 2015.

[50] C. Hawksworth, A. Asbury, and K. Millar, "Music in theatre: not so harmonious: a survey of attitudes to music played in the operating theatre," Anaesthesia, 52(1): 79-83, 1977.

[51] Y. Ullmann, L. Fodor, I. Schwarzberg, N. Carmi, A. Ullmann, and Y. Ramon, "The sounds of music in the operating room," Injury, 39(5): 592-597, 2008.

[52] J. D. Katz, "Noise in the operating room," Anesthesiology: The Journal of the American Society of Anesthesiologists, 121(4): 894-898, 2014.

[53] V. S. S. N. Murthy, S. K. Malhotra, I. Bala, and M. Raghunathan, "Detrimental effects of noise on anaesthetists," Canadian Journal of Anaesthesia, 42(7): 608, 1995.

[54] B. Hodge, J. Thompson, "Noise pollution in the operating theatre," The Lancet, 335(8694): 891-894, 1990.

[55] J. Makama, E. Ameh, and S. Eguma, "Music in the operating theatre: opinions of staff and patients of a Nigerian teaching hospital," African health sciences, 10(4), 2010.

[56] M. Cooke, W. Chaboyer, P. Schluter, and M. Hiratos, "The effect of music on preoperative anxiety in day surgery," Journal of advanced nursing, 52(1): 47-55, 2005.

[57] S. Koelsch, J. Fuermetz, U. Sack, K. Bauer, M. Hohenadel, M. Wiegelet, W. Heinke, "Effects of music listening on cortisol levels and propofol consumption during spinal anesthesia," Frontiers in psychology, 2, 58, 2011. 